\title{
The Politics of Wet System Building: Balancing Interests in Dutch Water Management from the Middle Ages to the Present
}

\author{
Cornelis Disco and Erik van derVleuten
}

\section{Introduction}

The Netherlands is a country physically structured by water. In addition to many minor rivers and canals, three large European rivers-the Meuse, the Scheldt and the Rhine-meander their way through the country towards the North Sea. A flat topography mostly at or below sea level is combined with a relatively high population density and wealth. It is hardly surprising, then, that the Netherlands have long been prominent in the development of water-related technologies, ranging from massively applied land reclamation (starting in the Middle Ages) and the adaptation of windmill technology for drainage (since the $15^{\text {th }}$ century) to the development of the world's largest seaport in Rotterdam and several large scale damming projects (the Zuiderzee; the Rhine, Meuse and Scheldt estuaries) in the $20^{\text {th }}$ century.

In this paper, however, we will not focus on isolated feats in the international history of technology. What makes the history of Dutch water management truly interesting is the complex adjudication of very different and potentially conflicting social interests in water flows. For in this intensively cultivated country, the same bodies of water might be subject to flood protection measures, land reclamation, inland navigation, fresh water supply for agriculture, industry and cities, waste water disposal, recreation, fish-

Cornelis Disco is the editor of the section on Water Management Technology in the Dutch national history of technology programme Technology in the Netherlands during the $20^{\text {th }}$ century, organised by the Foundation for the History of Technology. Erik van derVleuten writes about the development of large technical systems, including water-based systems, in the same programme. Both are at Twente University/Eindhoven University of technology and may be reached at <e.b.a.v.d.vleuten@tm.tue.nl> 
ing and even military defense (the last" water defense line"was constructed during the Cold War).

We shall focus upon the accommodation of these different social interests in the practice of water management as well as in technical design. For this purpose we shall draw from the analytical framework of large technical systems that has been developed in the sociology and history of technology over the last two decades. For a general introduction to this framework we refer to the introduction to this volume. ${ }^{1}$ Here we shall only observe that it suits our research interests because it is explicitly designed to study the messy sociotechnical complexity of infrastructural technologies. As a research topic, it inspires the analysis of the shaping of individual hydraulic artifacts not as a goal in itself, but as related to the performance of large and possibly nation-wide or even transnational infrastructural systemsfor navigation, drainage, water supply or defense. And as a research methodology, its lead concept of" system building"draws attention to the process in which certain historical actors (the "system builders") manipulate and juxtapose heterogeneous (technical as well as non-technical) elements into one sociotechnical whole. This concept combines several important virtues. Its immanently multidisciplinary character (system builders constantly cross disciplinary borders), exposing the multiple interrelations between the social and the technical, makes it a welcome addition to existing studies of Dutch water management from technological, economical and institutional perspectives. ${ }^{2}$ Furthermore, it opens the analysis for actors and actor processes that are so often lacking in studies of systems and structures. Most of all, a focus upon system building as an actor-process may show how different social interests were balanced and eventually accommodated in the actual design.

This last issue, however, demands a slight adjustment of the research focus. LTS-studies originally studied the perceptions, problems and actions of individual system builders, providing new insights into the construction and management of systems ${ }^{3}$ but-inasmuch as they were concerned with great men pursuing their projects-less sensitive to uncovering conflicts between actors and their impacts on technical design. ${ }^{4}$ LTS scholars who have extended the notion of system building from individuals to large organizations or even "institutional frameworks, "'institutional regimes" or "governance structures" (involving actors, institutional structures, and rules of system building) have, in our opinion, paid insufficient attention to this matter. ${ }^{5}$ Even Kaijser's study of the institutional frameworks of early water control systems, to which this study is much indebted, largely ignores other uses of water which might interfere with water control, and therefore pays insufficient attention to the high conflict potential that makes wet system building so complex. ${ }^{6}$ In this paper, we shall use the concept of 'regime of wet system building to denote a historically specific constellation of actors representing different uses of water. In other words, these regimes reflect and define how and which social interests in water are accommodated into the system-building process and ultimately into the technical designs. 
The first section of this paper distinguishes four regimes of wet system building from the Middle Ages to the present, which accommodated potentially conflicting social interests in water flows in radically different ways. The second section zooms in on the regime that dominated most of the $20^{\text {th }}$ century, and studies the delicate politics of technical design at the micro level of two selected cases: the canalization of the river Meuse in the 1920s (a "link" in the wet network) and the construction of the Haringvliet locks in the Southwestern delta after the Second World War (a crucial"network-node"). Both cases bring out the complex interplay between the variety of social interests and the design process, which is a particular feature of the construction of water-based large technical systems as compared to other types of infrastructural technologies.

\section{Balancing interests in regimes for wet system building: A long term view}

\section{The settler-village regime and the origins of Dutch water management}

Prior to 800 A.D. in the region that was later to become the Netherlands, humans had primarily adapted" passively"to the water situation. They simply chose to live on higher ground. If they colonized swampy areas, they situated their farms or villages on grounds that were gradually heightened with clay and manure (so-called terpen). ${ }^{7}$ The first institution to actively embark on wet system building was the settler village, which developed and flourished between the $9^{\text {th }}$ to the $13^{\text {th }}$ centuries. Groups of settlers drained peat bogs, which constituted a very large part of the territory, by digging systems of parallel ditches, creating fertile agricultural land that provided the basis for villages. Historians distinguish two types of reclamation settlements. In the $9^{\text {th }}$ and $10^{\text {th }}$ centuries and primarily in the Northern regions, reclamation initiatives were framed by the councils of the egalitarian Frisian villages. By contrast, in the Western and Central regions a feudal structure developed, and in the $11^{\text {th }}$ and $12^{\text {th }}$ centuries the feudal lords founded new settler villages in a successful attempt to imitate the Frisian reclamation projects. Reclaimers were offered a degree of personal freedom in return for paying taxes and serving as soldiers in times of war. But even here the village council, in addition to other tasks, bore the brunt of coordinating the building of canal systems for drainage.

The impact on landscapes was enormous. Extensive tracts of peat bog were transformed into fertile agricultural land. On the other hand, an unintended effect of reclamation was the lowering of ground level (by several meters within a couple of centuries) due to oxidation and decomposition of the peat after drainage. Much of the land became vulnerable to floods, which caused a perforation of the coastal line and the shaping of large inner seas and lakes, in short a large loss of of land. As a response to increasing flood threats, humans developed a range of water control technologies. The capacity of drainage canals was increased, and villages took on the construction of dikes. Originally erected around individual villages, 
in the $12^{\text {th }}$ and $13^{\text {th }}$ centuries dikes were joined together to form long uninterrupted chains along the coasts and rivers. In the feudal areas, the necessary coordination between villages was provided by the feudal lords. In the North, the Frisians invented regional organizations (called ambachten) for this purpose. Still, coordination was organized on a geographical basis: each village was responsible for the part of the dike in its vicinity. In his above-mentioned study of early institutional regimes for water control, Kaijser therefore concludes that the building of dikes was integrated into the existing institutional framework of the village. ${ }^{8}$ Within the village, every landowner had responsibility for a part of the dike and the drainage system. The village council organized inspections.

Obviously even in these early days water was used in various ways. Fishing had been an important activity for centuries, and the beginnings of an inland navigation system had emerged as early as the $10^{\text {th }}$ century: The Frisian counties were among the few areas in Europe with a money economy, navigating the North Sea as well as the Rhine (which they accessed via its northern delta system), and constituted a trade link between the Byzantine and Frankish empires. Information about possible conflicts between different uses of water is scarce, but it is important to note that these different uses of water were often united in the same users. AsVan de Ven observes, "people were farmers, sailors and tradesmen all in one." Also, the village councils-as institutions for the common weal-were wellsuited to balancing different interests. Co-ordination between functions was thus a matter of the individual or the local village council, and the representation of different water uses not yet clearly differentiated.

\section{A preindustrial regime for wet system building}

In subsequent centuries such a differentiation did take place, starting with the emergence of specialized bodies for water control, later known as water boards (waterschappen). Today these still constitute a local level of government next to municipalities. From the late $12^{\text {th }}$ century onwards, the feudal lords in the principalities of Holland and Utrecht founded large regional water boards in order to build dams with discharge sluices in river mouths or canals. These prevented the intrusion of (salt) water during high tides while allowing for drainage at low tides. Serving perhaps some twenty villages, these dams challenged the capabilities of the existing institutional framework. ${ }^{10}$ Emerging also in the North, these regional institutions later acquired other responsibilities such as organizing dike and canal inspections, resolving conflicts among villages and imposing fines. In the $15^{\text {th }}$ century, such specialized water boards began to emerge at the local level as well, and a framework emerged in which local boards were responsible for local water control systems, and regional boards for the major canals (so-called boezems) carrying of the water from these local systems. Inasmuch as the large landowners dominated these water boards, drainage, and the associated agricultural yields, was prioritized as the most important function of water management. Other, conflicting uses such as fishing and navigation (obstructed by dams) had to yield. 
These other interests were represented at least in part by different institutions, which tended to build their own systems. For instance, the powerful and nearly autonomous cities managed to create extended networks for inland navigation. ${ }^{11}$ Particularly after the crisis of the Dutch revolt had passed in the 1580s, the rapidly expanding cities organized regular freight and passenger transport, appointing skippers to sail according to fixed time schedules. By the mid $17^{\text {th }}$ century the interurban transportation system included every city of any importance. In addition, from the early $17^{\text {th }}$ century so-called market boat services were established between cities and their rural hinterlands. Finally, between the 1630s and 1660s the cities built a separate canal network to accommodate"rapid"passenger traffic by horsedrawn barges. This "pre-industrial mass transportation network" included some 650 kilometers of canals connecting some 30 cities, and was responsible for more than a million trips a year. ${ }^{12}$

The Republic's military authority was yet another wet system builder, in possession of a system for rapid strategic inundations of the countryside for the purpose of national defense. This technology had been pioneered during the Dutch Revolt in the 1570s, where it was responsible for breaking the lengthy and nearly successful Spanish sieges of Leiden and Alkmaar. The surroundings were inundated by blowing up strategic dike segments, and the Spanish had to abandon their positions and flee to higher ground. After the improvised flooding of many connected polders to create a long water defense line that actually stopped Louis XIV's mighty army before it reached the military and commercial gravity center of the Republic, this military technique began to be "engraved" in the Dutch waterway system in the form of a number of permanent water defense lines. This involved the construction of strategically placed inundation sluices, and of special fortresses to protect the remaining transport routes, the higher roads and dikes. ${ }^{13}$

Fourth, rich urban merchants in search of profitable investments initiated a new wave of land reclamations. They founded joint-stock ventures to finance large reclamation projects making extensive use of windmill technology. The newly reclaimed land could subsequently be rented or sold at a profit. In the case of the large Beemster Lake (7000 hectares) near Amsterdam, over a hundred investors were involved in a project involving forty-three windmills. In the $16^{\text {th }}$ and $17^{\text {th }}$ centuries more than 150,000 hectares of arable land were reclaimed. ${ }^{14}$

Finally, the provinces that together constituted the Republic might occasionally carry out water works of their own, for example, assuming responsibility for the large rivers. A major achievement was the stabilization of the division of Rhine water over its major branches in the mid $18^{\text {th }}$ century, a feat made possible by cooperation between Provincial authorities (but after considerable disagreement and strong external pressure from Prussia which demanded a navigable Rhine). ${ }^{15}$

Thus, mirroring the decentralized structure of the Dutch Republic, a regime for "parallel" wet system building had emerged characterized by a number of system builders independently building wet systems for specific functions. These were of course physically connected by water and 
affected each other. But coordination remained minimal. It has been observed that co-operation between cities and water boards was poor; before the introduction of a separate canal network, there had been many conflicts around the generally irreconcilable combination of drainage, damming and navigation. ${ }^{16}$ Likewise, there was almost no cooperation between water boards and military authorities. ${ }^{17}$ The state authorities hardly anticipated conflicts between different system builders. At most they responded through the legal system once conflicts had arisen.

\section{Rijkswaterstaat and the creation of a centralized regime}

In the centralized state that succeeded the decentralized Republic in the last decade of the $18^{\text {th }}$ century, water management was seen as a task to be managed by the national government. Gradually, the preindustrial regime of parallel system building gave way to a regime of centrally coordinated system building. To support the authorities, a national engineering corps was created in 1798 to initiate and manage waterworks of national importance, and to supervise all hydraulic activities at lower levels. It has survived to this day under the name of State Water Service (Rijkswaterstaat) and is at present the main executive engineering agency of the Ministry of Transport and Water Management. ${ }^{18}$

With the advent of the Rijkswaterstaat, the task of juggling various interests and associated wet systems fell to the responsible Minister, his technical advisors, and, later, Parliament. To start with, the central state took over the construction of a range of wet systems - under the proviso that they be of national interest. In practice, the apportioning of responsibilities and priorities varied over time. In the $19^{\text {th }}$ century, the state focused upon the "improvement" of the large rivers by constructing three new river mouths, upgrading river dikes, and normalizing hundreds of kilometers of river. In addition, the state reclaimed several large lakes in the province of Holland, which threatened to transform the central region between Rotterdam and Amsterdam into one vast unmanageable body of water. Finally, the national state constructed some $800 \mathrm{kms}$ of canals to create a new navigational infrastructure succeeding the above-mentioned barge networks. ${ }^{19}$ In the $20^{\text {th }}$ century the improvement of coastal flood defenses claimed priority. In the course of that century the total length of coastline was reduced from some $3400 \mathrm{kms}$ to some $650 \mathrm{~km}$, thanks primarily to the closing off of the Zuiderzee, a large inland sea, in 1932 and to the damming up of the estuarine river mouths in the Southwestern delta after World War II. Finally, between 1940 and 1970 the Rijkswaterstaat created a nation-wide system for the distribution of fresh water to cities, agriculture and industry across the country. ${ }^{20}$

Being responsible for a variety of social interests, the state faced mul tiple demands in the construction of concrete water works. For instance, river improvement was aimed simultaneously at improving the drainage capacity and the navigability of rivers. Likewise, the damming of the Zuiderzee was motivated by an immediate political need to ward off future floods as well as concerns for improved infrastructural connections (the 
dam carries a road), reclamation of new arable land yielding long-term economic gains, the creation of a large freshwater "cachement" to improve drainage and irrigation of the Northern provinces, and the short-term national interest in countering massive unemployment. In the case of the post-war construction of a nation-wide fresh water supply system, seemingly incompatible interests were ultimately combined: the final design allowed the navigability of different stretches of river, fresh water supply to the North (the city of Amsterdam and the agriculture of three provinces) and to the West (the city of Rotterdam and the intensive greenhouse agriculture of the Westland), the disposal of sewage from the large cities, as well as the reclamation of new land. ${ }^{21}$

Two observations about this centralized regime for wet system building are apposite. First, in addition to conflicting interests on the national level there remained many tensions between national interests and regional or local levels. The Rijkswaterstaat exercised its supervision mainly through negotiation, leaving much autonomy to the provinces and local and district water boards. Even after a truly hierarchical relationship was enacted by law in the early $20^{\text {th }}$ century, lower authorities retained considerable autonomy and countervailing power. ${ }^{22}$

Second, even within this centralized regime one may distinguish several styles of wet system building. Lintsen has divided the history of the Rijkswaterstaat into an "aristocratic-artisanal period" during the reign of the enlightened despot King William I, succeeded by a "democratic-mechanical period" in which Ministers were responsible to Parliament and steam-power enabled large scale works. By the 1930s a "technocratic-scientific period" had set in, marked by a scientific approach to hydraulic engineering, and relatively powerless Ministers and Parliament. ${ }^{23}$ The adjudication of "wet" interests occurred mainly within the civil service organization, which translated political issues into technical problems and designed solutions. When these were offered to politicians for debate and decisions, the important choices had implicitly already been made. According to another historian, and many critics, the Rijkswaterstaat had become "a state within a state." 24

\section{Towards a post-modern regime of wet system building}

The historian Thomas Hughes has observed a crisis in large technical system building in the United States starting in the late 1960s. With the emergence of the counterculture and the delegitimization of military systems in the Vietnam war, technocratic system building encountered such massive popular opposition that certain planners believed that the days of large-scale system building were numbered. However, out of this crisis emerged a new style of system building, inspired on a form of participative management congenial to the values of the counterculture and the social, political and environmental complexity of postindustrial societies. Contrary to technocratic "closed" system building, a new generation of system builders created "open" or"post-modern"system building process in which 
interested parties (e.g. the public, NGOs and regional and local government) were invited to participate..$^{25}$

The recent evolution of Dutch water management is a case in point. As recently as the late 1960 s the Rijkswaterstaat tended to frame the future as a simple extrapolation of the heroic past. Its policy memoranda envisaged ever more bold projects in hydraulic infrastructure. The opposition, which had been gaining momentum since the mid 1960s and which had gained broad popular support by the early 1970s, took the government engineers by surprise. In the popular view, the 'great builders' had become authoritarian pillagers of water and land, agents of the devastating face of modern industrial civilisation.

As in Hughes' examples, a number of planned projects suddenly ran into serious trouble. For instance, the fifth and last of the projected reclamation projects (the Markerwaard polder) in the enclosed Zuiderzee (the fourth had been completed in 1968) was already under way when the plan to situate a second national airport there inspired a coalition of local NIMBY groups and well-established national environmental groups. The issue was put on the national political agenda, where environmental values as well as the growing rift between government and citizens had become important concerns. The center-left government elected in 1974 was deeply committed to citizens' participation in decision-making processes, and to deal with crises like the Markerwaard it established a new procedure. Thenceforth, construction projects of national importance would first have to run a gantlet of formal public hearings in which interested parties could air their views and objections. System builders like the Rijkswaterstaat had to hear several specialist commissions as well as interest groups and individual citizens. On the basis of the testimony, Parliament itself would come to a final decision. In the Markerwaard case, the Rijkswaterstaat's motives and options were deemed so politically unconvincing that to this day the project remains stalled. ${ }^{26}$

The pace of system building slowed down considerably in the 1970s and 1980s compared with the previous two decades, and there was widespread pessimism about the future of large-scale wet system building. But here too system building would revive. The closing of the Oosterschelde estuary became the main learning experience for a new approach to water management in the 1980s and 1990s. ${ }^{27}$ The Oosterschelde dam was to be the largest in the ambitious project to close off the South-Western Delta from the sea, a project enjoying broad popular support in the wake of a catastrophic flood in 1953. It would also create a new freshwater basin, and therefore seal the fate of the prosperous mussel and oyster industry in the area. This led to serious discussions on alternatives. The Rijkswaterstaat, however, preferred the dam option for safety reasons and the function the new basin could play in the freshwater supply system. In the best technocratic style, the various interests were weighed, and it was conclude that a fixed dam was the best option. The disadvantaged parties-the mussel and oyster industry - were to be financially compensated.

However this scenario derailed in mid-course. In the early 1970 s fishermen, biologists, pleasure craft owners, and national environmental groups 
united in a renewed plea for an open Oosterschelde. As in the case of the Markerwaard, the question became a national issue. The national government appointed an independent committee to study the matter once again, in which-in a radical departure from previous usage-civil engineers did not predominate and Rijkswaterstaat was not even represented. The committee recommended a semi-permeable dam that would be closed only during storm surges, and Parliament agreed, pending proof of technical and financial feasibility. In the event, a rejuvenated Rijkswaterstaat managed to design such a dam: 66 huge caissons, 45 meters apart, support gigantic gates which can be lowered to sever the Oosterschelde from the sea during storm surges. The project was completed in 1986 and remains today the pride of Dutch hydraulic engineering. ${ }^{28}$ The costs were high in financial terms; the Oosterschelde storm surge barrier cost twice as much as all the other works combined (some ten dams) in the South-Western Delta project.

In the 1980s, this experiment with open system building, in which a number of interests were allowed to affect the design process, was formalized into a new doctrine of so-called integrated water management. A Ministerial policy memorandum (1985) developed this concept explicitly as a technical and management solution to the complex multifunctionality of wet systems. ${ }^{29}$ This principle was adopted and elaborated by Rijkswaterstaat in its Third Memorandum on Water Management (1989). ${ }^{30}$ Integrated water management denoted on the one hand a systems approach to bodies of water, in which a variety of interests was translated into qualitative parameters, which subsequently were quantified and related in a systems model. On the other hand, it denoted the administrative integration of heterogeneous interests, responsibilities and organizations on several levels of administration. The entire gamut of user functions and users was to be included in the design process, but the decisive power was situated at water management agencies. In this way, special interest groups were included in the process, but also in a sense pacified: the representation of their values within the system building regime was also a strategy to minimize the chance of massive political protests of the kind that had paralyzed wet system building in the 1970s. ${ }^{31}$ Thanks to the new regime of centrally coordinated, but relatively open system building, the 1990 s again saw a revival of optimism and the framing of new large projects. These include a new'Delta plan' for large rivers in response to severe flooding in 1993 and 1995, and a novel type of storm surge barrier in the Nieuwe Waterweg, completed in 1997.

\section{The micropolitics of design}

How, then, did system builders operate in these regimes? How did they embed potentially conflicting uses of water into the technological design of water works? In this section we shall present two cases that have been investigated in detail in the research programme Technology in the Netherlands during the $20^{\text {th }}$ Century. In the twentieth century, the increasing scale of wet system building made coordination between different functions increasingly critical: to use Perrow's phrase, water-based systems grew increasingly 
tightly coupled. We shall focus on the historical era dominated by the regime of centralized and even technocratic system building, which shaped the background for more recent institutional discussions and developments as well as the actual hydraulic artefacts that constitute the material backbone of the current wet network. In this regime, as noted above, the engineers of the Rijkswaterstaat were able to carry out complicated works in a relatively uncontested way, as they were regarded as the only qualified national experts and hence enjoyed relativepolitical autonomy and great popular respect.

\section{Canalizing the Meuse}

In the period 1918 to 1928 , the Rijkswaterstaat canalized a portion of the River Meuse in the Province of Limburg. The engineers were aware that canalization entailed not only transforming the river as an artery of commerce, but also potentially transforming it as an artery of drainage. After canalization, drainage and transport systems would coexist intimately as different functions of the same physical human-built structure. Whether this could succeed without impeding transport or aggravating the chance of flooding depended chiefly on how the shipping locks and the large moveable weirs were designed.

Around 1910 two major traditions of weir design had emerged.The first tradition utilized structures composed of numerous small elements that could be manipulated by hand. The original inspiration was the "needle weir" invented in 1843 by Poirée, an engineer of the French Ponts et Chaussees. Though such weirs were laborious to maintain, manage, and remove from the river in times of flood, they were capable of spanning almost any channel width and so were especially favored where navigation required wide channels.

The second tradition was emerging out of monolithic types of moveable weirs developed around the turn of the century, primarily by large German steel-construction firms seeking better-regulatable weirs for hydroelectric power plants. ${ }^{32}$ These moveable weirs had only one or two very large moveable riveted steel elements, cylinders or gates with spans originally of around 10 meters and by the late 1920s of up to 40 meters long, which could be lowered into the river or raised as needed to control discharge and maintain a particular water level. As modified for use in canalization projects, the new weirs had the advantage of rapid response times, cheapness of operation, reliability and simplicity of construction. These new types of weirs were made possible by revolutionary developments in steel construction, reinforced concrete (for the fixed piers and beddings) and by the development of dependable electrically powered drive mechanisms. It was clear to all that by comparison with the baroque complexities of the hand-powered older weir types, these new monolithic weirs were impeccably" modern."

Canalization of the Dutch Meuse achieved political viability only after the development of state-run coal mines in the southern province of Limburg around the turn of the century. Details of the canalization project were worked out by a joint "Dutch-Belgian Commission for the Investiga- 
tion of the Canalization of the Common Meuse."The commission was appointed in 1906 and submitted its final report in 1912. ${ }^{33}$ International agreement was necessary because the Meuse formed a common border with Belgium for some $60 \mathrm{~km}$. It was quickly agreed that the new waterway should be dimensioned to Rhine standards. This implied a navigable channel width of at least 60 meters.

Of course this ambitious nautical requirement could not be allowed to compromise the river's original drainage function. The two sets of criteria together implied a weir which could maintain prescribed navigational depths despite rapidly changing and highly variable river discharges and which in times of flood could be easily and reliably removed from the river in order to provide a navigational channel of 60 meters width and an unobstructed discharge. This suggests an impossible combination of the two traditions in weir design. However, while there was no way to fuse the small and big element traditions into one single weir opening, it was already common practice to design hybrid weirs in which the different functions were performed by different types of weirs placed end-to-end across the river. Generally speaking, the small-element weirs were used in the "navigational channel" because they allowed for large openings between the weir abutments. The large-element weirs because of their accuracy were well suited to regulate discharge and were employed, sometimes in parallel, for this function. Their relative "agility" also meant that the weir could effectively be "struck" in much less time than would be necessary if the weir will composed entirely of small elements.

By the time of the Dutch Meuse canalization, it would in principle have been possible to use the new large weir elements in either the navigational opening, the discharge opening or both. However, given the stipulated $60 \mathrm{~m}$ channel width, modern monolithic weir constructions with their maximum spans of at most 20-30 meters were ruled out for the navigational opening. In fact, the Commission explicitly recommended a variation of the tried and tested Poirée system, with vertically moveable plates between the yokes instead of vertical needles. For the discharge openings, however, the committee prized the large-element solution.

A construction with large elements is to be recommended in all respects for the discharge openings; these have to provide passage to discharges during small, often sudden increases in flow, to allow for the passage of ice-floes and floating objects, and consequently to have a means of closure which it is possible to regulate or remove under all possible conditions. ${ }^{34}$

With the advent of World War I and the occupation of Belgium, the joint project fizzled. The (neutral) Dutch government proceeded with the part of the project downstream from the border Meuse. Instead of the 11 weir-lock complexes projected for the complete canalization, only four remained. The three upstream weirs were of the hybrid construction recommended by the Joint Commission: a long chain of small elements closing off a 60 meter navigation opening joined to two or three 17 meter wide discharge openings closed off with single large elements-specifically, double Stoney-gates. 
A weir too far?

The final episode of the canalization project involving the design of the fourth, downstream, weir, is a perfect example of what was referred to above as the "technocratic-scientific" style of hydraulic engineering. The debate about the merits of different designs took place almost entirely within the confines of the Rijkswaterstaat bureaucracy, although the responsible minister intervened at critical points. Different Rijkswaterstaat engineers were tacitly representing the different systems interests, rather than social groups acting through public forums like parliament or the newspapers.

The fourth weir was projected at a site near the town of Grave where the Rijkswaterstaat was planning to replace the ferry by a new roadway bridge. This provided an opportunity to build a so-called "bridge weir," a construction in which the weir elements were suspended on hinges from the bridge and could be removed by winching them up out of the water. This was a small-element type of weir developed in France in the 1870s. Given the bridge, such weirs were relatively cheap to build and they had proved effective in long practice. Although the many small wheel-gates were more difficult to regulate than the big Stoney gates in the upstream weirs, the Grave weir did not demand such intensive regulation and it was not considered necessary to build special regulative openings. The entire breadth of the navigational channel, i.e. 60 meters, would thus be spanned by a chain of small and quickly removable elements.

The bridge weir was a preliminary design by the Meuse department of the Rijkswaterstaat. Before funding, it had to be approved by the Minister of Public Works.This same minister had only two weeks previously approved a new weir (at Borgharen, near Maastricht) consisting of three large identical 30 meter long wheel-gates. This decidedly modern structure had been designed and constructed in the workshops of the prestigious Dortmunder Union engineering works, at the behest of the Rijkswaterstaat's Juliana Canal department. The weir was not part of the actual Meuse canalization and did not need to accomodate the very largest ships. That was why the 30 meter span was sufficient and why large elements could be employed.

Nonetheless, the contrast between the modern design for the Borgharen weir and the antiquated design proposed for Grave was so glaring, that the minister felt compelled to call the competence of the Meuse department into question. Although that department's chief engineer energetically defended his proposed bridge-weir design-and also the 60 meter wide channel which would rule out large elements--his immediate superior thought otherwise and advised the minister accordingly. With dissension in the ranks about the optimum resolution of navigation and drainage requirements in the design of the weir, (and with Borgharen on his mind) the minister took his engineering corps to task:

To my regret, I have not been able, while studying the various reports, to disabuse myself of the impression that the development of weir construction has been insufficiently followed by the Rijkswaterstaat ... and that the agency has 
held fast to the small-element type of weir originally adopted for the Meuse canalization, without considering whether it might not be desirable, given the technical progress that has been made, to abandon this type. ${ }^{35}$

The controversy surrounding the Grave weir shows that superimposing different functional systems on the same wet substrate is not a question of following some recipe. Instead, perceptions judgements and conflicts are central. Requirements are not given, but are agonistically constructed by the system builders.

The specific bone of contention in this case was that big elements facilitate discharge functionality but tend to hinder shipping, while small elements serve stringent navigational demands while compromising discharge safety and accuracy of regulation. So the fight between big and small elements not only a fight between tradition and modernity, but also a fight between priority for shipping vs. drainage functions. Or to put it another way, between the river as a managed quasi-artificial element of the drainage system and the river as an element of large international inland navigation system.

Figure 1. Longitudinal Profile Meuse Canalisation. This figure (with a greatly exaggerated vertical axis) shows the 15 weir-lock complexes originally programmed by the Dutch-Belgian Commission. Ultimately only complexes 11-15 were built, the other portion of the river being circumvented by a lateral canal. The succession of canal pounds is clearly visible.

Figure 1

\section{Longitudinal Profile Meuse Canalisation.}

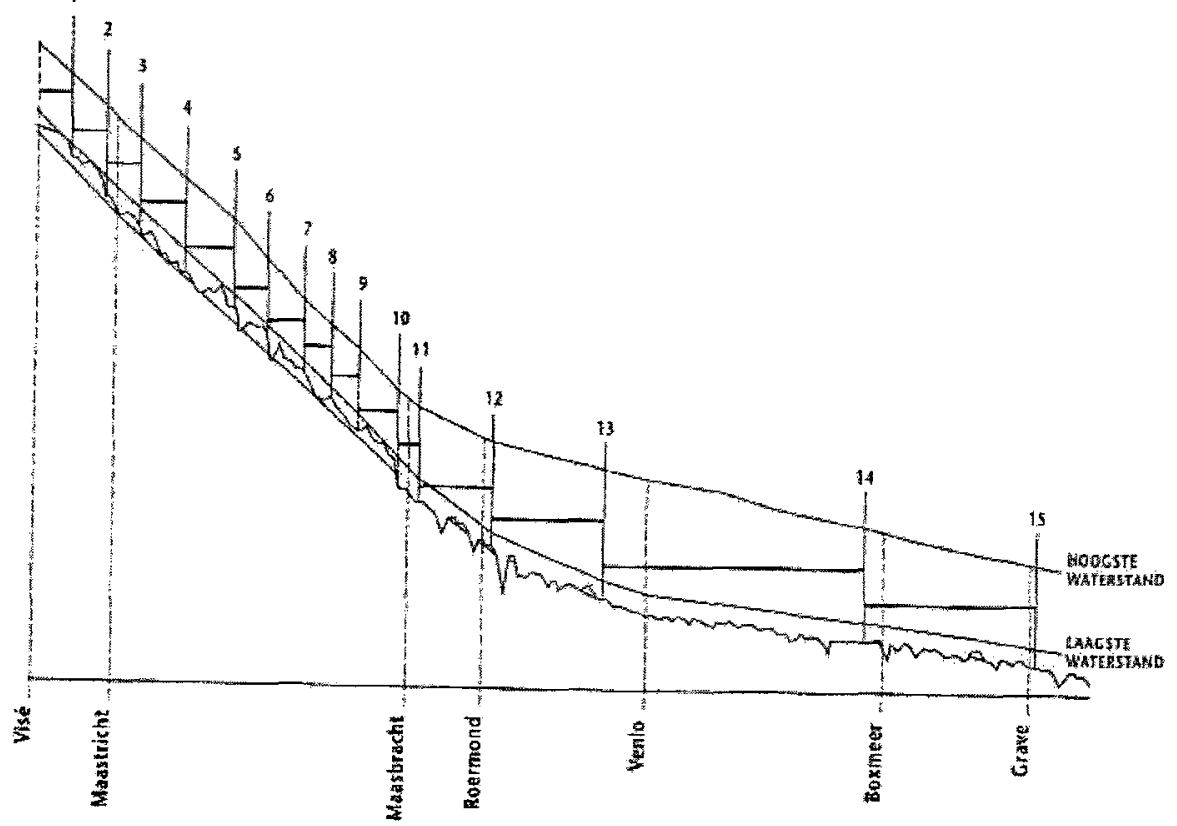




\section{The nine lives of a protean systems node:The Haringoliet Sluices}

The second case spans two of the water management regimes noted above. It begins at the zenith of the technocratic regime as one of the projects in the post-war Delta Works and continues on into the phase of open post-modern system building. It exhibits the transition from an authoritarian regime in which nature was still regarded as an implacable enemy to be subdued by all available means to a regime in which ecological concerns and political responsiveness became central values.

As in the case of the Meuse canalization, this project to build a large sea-sluice in the joint mouth of the Rhine and the Meuse (the Haringvliet), shows that different wet systems can be superimposed on the same bodies of water without undue interference only thanks to careful design of the necessary hydraulic artifacts. In this case, the sluices were already managing a number of different functions when, years later, they were called upon to assume a role in a reconstructed ecological system. Remarkably, the sluices required no structural alterations to perform this new function-a consequence of the flexibility that had been part of the original multipurpose design.

The construction of the sluices, part of the huge Delta Works project, was a direct response by the government and the Rijkswaterstaat to the severe storm of February 1, 1953 which had burst through the dikes around the southwestern estuaries in more than 100 places, killing some 1,800 people. In the wake of this catastrophe, a plan was forged to close off all the Rhine and Meuse estuaries between the Rotterdam Waterway and the Westerschelde (see map). The aim was a dramatic reduction of the length of primary and vulnerable coastal dikes. An added benefit would be the creation of several large freshwater lakes to act as storage basins for irrigation and drinking water. However, this radical reconstruction of the delta threatened to conflict with its vital role in the national drainage system. The estuaries in question were also the mouths of major rivers. Although two undammed exits to the sea-the approaches to the harbors of Antwerp and Rotterdam-would remain, they could hardly cope with an ice-jammed Rhine or a rain-swollen Meuse in flood.

Hence a large discharge opening was incorporated into one of the proposed dams. The natural candidate was the proposed Haringvliet dam across the common mouth of the Rhine and the Meuse. The sluice gates would be closed firmly at high tide to keep salt water out and open at low tide in order to let excess river water flow out to sea.

Other functions also loomed large in the design of the sluices. For one thing the location of the proposed sluice enabled it to be used as a kind of giant valve to regulate the apportionment of Rhine water between the Rotterdam Waterway and the Haringvliet. In essence, the tidal sluice, by dint of proper design, could also function as a weir to regulate upstream water levels. Manipulating the weir's regime at low tide and hence regulating the water level in the Haringvliet would make the route to the Rotterdam waterway more or less"inviting"for runoff from the Rhine/Meuse 
and hence determine the amount of water flowing past Rotterdam to the sea. Being able to manage this flow was an important tool in fighting the increasing salinity of the Waterway caused by its continual enlargement in the service of shipping. The advancing "salt-tongue" threatened the fresh water supply situation all along the Waterway, from irrigation for the vulnerable greenhouse farming region of the "Westland," to Rotterdam's municipal water supply. By ensuring a minimal fresh water flow, sufficient counterpressure could be maintained to keep the salt-tongue at bay.

On the other hand, of course, too much water would hinder shipping because of excessive currents. Hence, the Haringvliet"weir" also had to be able to manage the full flow of the Rhine and Meuse in flood. In other words, the "weir" - like the Meuse weirs further upstream-had to be completely removable so as to restore the full cross-section of the sea-sluice.

This multifunctionality of the Haringvliet sluice is reflected in its design, the result of several years of sometimes acerbic debate within the Rijkswaterstaat. The main design criteria were robustness and reliability on the one hand, and discharge capacity and regulability on the other. Given the tradeoffs between discharge capacity (for which large openings were required) and robustness, finding an optimal solution was no easy task. Among the many possible options for closure elements, the choice finally fell on segment gates, i.e. gates supported on long arms that pivoted vertically around a point. (see figure: cross-section Haringvliet sluices) These were considered to have a number of structural and operational advantages, in particular, ease of raising and lowering even when loaded by large water-level differences. In view of the critical role of the sluice, both as an element of the coastal defense system and as an element of the fresh water supply system, it was thought essential that per sluice opening each of the two segments be a fully functional back-up for the other. This is the main reason for the apparently symmetrical construction of the sluice, with one segment facing seaward and one facing land-inward. On closer inspection the sluice is not perfectly symmetrical. For one thing, the seaward gate is somewhat lower than the landward one. The idea is a kind of division of mechanical stress between the two gates when the sluice is being impacted by gale-driven waves. The height of the seaward gate is such that the largest waves will break over this gate. That portion of the wave spilling over the seaward gate will be stopped by the landward gate. Hence each gate takes part of the burden. Nonetheless, the gates are so designed that even if one should fail, the other could hold the fort until repairs are made.

Looking at the sluice as a weir for retaining fresh water coming from upstream, the segment gates similarly back each other up. Either of the gates can be raised from its sill the requisite amount in order to regulate outflow and hence the water level of the Haringvliet. This is a complex matter, given the constantly changing tidal patterns at sea and the highly variable river discharges. Hence, from its commissioning in 1970, the sluice-gates have been computer-controlled. Each of the 34 gates can be independently raised or lowered in order to achieve the desired water level in the Haringvliet given expected rates of upstream discharge and the tidal situation. 
Figure 2

\section{Cross section Haringvliet sluices}

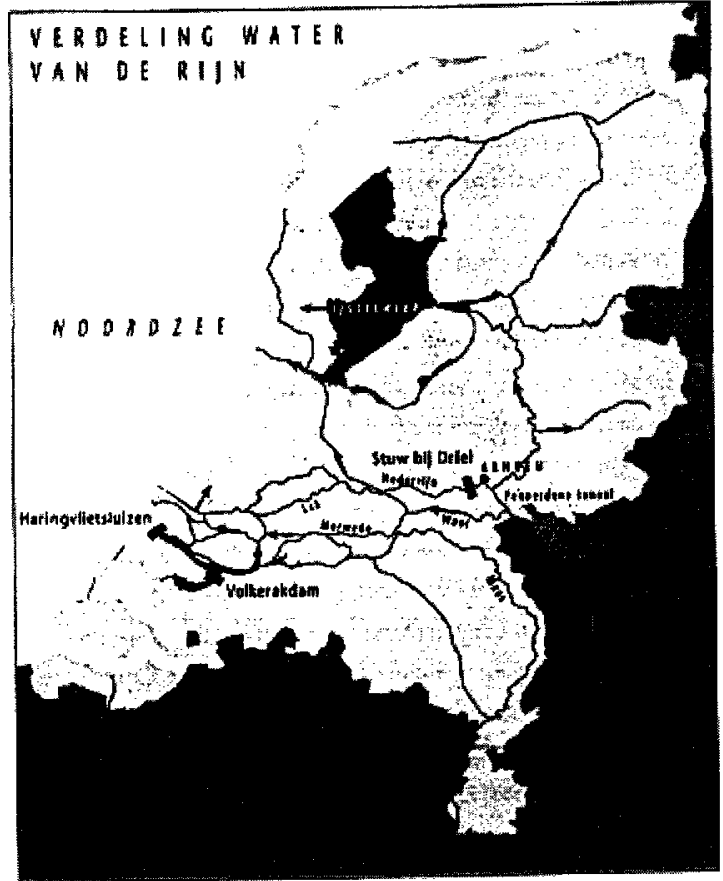

Hydraulic artifacts may also be enrolled into "dry" systems, particularly as means to cross rivers and canals. We have seen this already in the case of the weir at Grave, on the Meuse. The Haringvliet dam was also earmarked as an element of a coastal highway which incorporated several of the other Delta dams into its route as well. This additional requirement influenced the design of the triangularly shaped reinforced concrete beam which forms the structural heart of the sluice construction. So the total Haringvliet dam as designed is a wondrous point of intersection of at least five different systems, four of them water-based: drainage, freshwater distribution, inland navigation, coastal defense, and roadway transport.

\section{The ecological turn and post-modern system building}

In 1970 the Haringvliet dam went into service. The Haringvliet estuary turned fresh within a matter of weeks and a massive biological transformation of the entire region ensued. Salt water species died off and were replaced by a much more limited range of freshwater species. Especially hard hit were all kinds of tidewater and salt-marsh species which had thrived in the marshes and on the sandbanks of the estuary. It should be noted that at the time at least some Rijkswaterstaat engineers were quite aware of these environmental effects, but that they could not be seriously 
considered, given the huge safety and water management interests driving the construction of the dam and the sluices. Ecological concerns would have compromised these primary interests and were hence not represented in the technocratic regime. A 1955 conference on the Delta works concluded:

Safety absolutely demands the closure of the estuaries. In exchange a certain loss of our natural possessions must be accepted. But what is lost is no small thing. The dynamic character of the Delta region will be lost, possibly not entirely but certainly in large part. At most places tidal effects and saline gradients will inevitably be eliminated. In any case the three most important regions, the Oosterschelde, the Haringvliet and the Biesbosch will be totally transformed.

The consequence is that the bulk of the Delta planning region is facing a strong biological impoverishment. Numerous plant and animal species and even more unique combinations of species will be forever lost. The consequences will probably be even more extensive than we can now oversee. It is not unlikely that, even years hence, we will be facing unexpected problems. ${ }^{1}$

The past 15 years have witnessed an ecological turn in Dutch water management along with a turn to "post-modern" system building as described above. With this has come a determination to try to undo as much of the ecological damage as possible. This has posed a new challenge to the Haringvliet sluices. Now, aside from its many other functions it is being called upon to serve as an instrument of ecological restoration. The inherent flexibility of its programmable gates, which makes it possible to devise any combination of flows seaward or land-inward, has given life to the idea of restoring at least something of the original tidal and estuarine nature of the Haringvliet. What management regime to choose depends on reassessing the importance of the various system functions performed by the Haringvliet sluices. Ecological reconstruction is now in any case a political priority even if this means seriously compromising other functions-except, in extremis, safety. The "open" policy-making process around this project has resulted in an ironically inverted environmental impact statement. Instead of assessing the damage done to nature by some human project or practice, the study is assessing what damage will be done to existing infrastructure by the reinstatement of a partially saline environment in the Haringvliet. The study involves assessing the expected damage at four different levels of ecological reconstruction for existing human-made systems like fresh water distribution, inland transportation, coastal defenses, and drainage. Technological and social "fixes" for these damages are identified, and recommendations are made regarding the level of ecological reconstruction that can be financially justified. In the midst of this multi-dimensional "open" system building process, the protean Haringvliet sluices remain unchanged, ready for their enrollment in the maintenance of yet another human-made large quasinatural system-in this case the artificial ecology of a saline Haringvliet "estuary." 


\section{Outlook: The wet network and the LTS-field}

We have seen how the balancing of potentially conflicting interests was accommodated in different regimes of system building characteristic for different periods of time. We also analyzed in some detail how multiple uses were translated into multifunctional design during the era of wet technocratic system building. Thus we hope to provide a background setting for current debates on participation and globalisation in water management.

By way of conclusion, we can reflect back onto the body of LTS research, the sub-field in technology studies that specializes in sociological and historical perspectives on the development of infrastructural technologies. We have demonstrated that the notion of "large technical systems"can be usefully extended to such supposedly loosely coupled systems as those organizing the social management and uses of water. Moreover, we demonstrated that a broadening of the concept of "system building" from the perceptions and actions of individuals to the place of possibly competing organizations in regimes enables the study of the delicate politics of wet system building.

We can now position water-based systems in the overall classification of large technical systems. In his typology of large infrastructural systems (the most comprehensive typology in the LTS literature of which we are aware ${ }^{2}$, Kaijser characterizes systems by their function (energy supply, communication, transport) and the type of networks they use. For instance, (rail)road systems and electricity supply systems use artificial, human-built networks. By contrast, radio, air traffic and water transport systems use'natural' networks in the shape of water or air. In our study of water-based large technical systems (LTS) within the Netherlands, however, we find both distinctions challenged. Thus, the physical networks of such systems consist of network links like canals, (normalized) rivers, lakes and estuaries and network nodes in the form of hydraulic artefacts. From this perspective, waterbased LTS are natural-technical hybrids. In addition, the same wet network link can be used for a variety of functions. These include inland navigation, drainage, flood control, fresh water supply to cities, agriculture and industry, and-for a large part of Dutch history-military defence by creating "waterlines" to bar foreign invaders. In sum, in terms of functions water-based systems are hybrids too-they are multifunctional systems.

From these characteristics follow several properties of wet LTSs. Kaijser has observed how systems with artificial networks are expensive and generally develop slowly. Natural systems, by contrast, can be set up rather fast and cheaply as the network linkages do not have to be constructed. From this hybrid character it follows that in the case of water-based LTS, some parts of the system can be accomplished quickly and easily (mobilizing rivers for transport), while others are extremely labor and money intensive (like the construction of canals or large dams).

Also, the technique of coupling between different large technical systems may differ. Kaijser distinguished coupling by"junctions" and by"gate- 
way technologies." Road, rail and air transport networks are coupled in the junction of the airport. Likewise, gas pipes, warm water pipes for town heating, and the electricity grid meet in the gas-fired combined heat and power plant. The container is a gateway technology to connect different transport systems, just like converters couple direct current and alternating current in electricity supply systems studied by Hughes. ${ }^{3}$ Looking at our water-based systems, we can add a third kind of coupling to Kaijser's typology: different functional systems such as inland navigation, fresh water supply and drainage may share not only junctions (like sluices) or gateway technologies (like ships), but also the same material network-links (like a piece of normalized river performing all three functions). Obviously this intimate type of coupling makes the problem of coordinating the different functions even more compelling.

\section{Notes}

1. The paradigmatic study is Thomas Hughes, Networks of power. Electrification in Western society 1880-1930 (Baltimore: Johns Hopkins, 1983). For the history, positioning and basic concepts of the field see Jane Summerton, "Introductory essay: the systems approach to technical change" in Jane Summerton (ed.), Changing large technical systems (Boulder, 1994), 1-21.

2. The standard reference work is G.P. van de Ven (ed.), Man-made lowlands: history of water management and land reclamation in the Netherlands (Utrecht, 1996 (3rd ed.), Dutch orig. 1993). A number of reference works in Dutch has recently become available, incl. H. W. Lintsen et. al. (eds.), Twee eeuwen Rijkswaterstaat 1798-1998 (Zaltbommel: Europese Bibliotheek, 1998); Willem van der Ham, Heersen en beheersen. Rijkswaterstaat in de twintigste eeuw (Zaltbommel: Europese Bibliotheek, 1999); Antoon Bosch, Om de macht over het water: De nationale waterstaatsdienst tussen staat en samenleving 17981849 (Zaltbommel: Europese Bibliotheek, 2000); Eric Berkers, Technocraten en bureaucraten. De ontwikkeling, organisatie en personeel van de Rijkswaterstaat tussen 1850 en 1930 (Zaltbommel: Europese bibliotheek, forthcoming); C. Disco (ed.),"Waterstaat" in Schot et. al. (eds.), Techniek in Nederland ... Vol. 1, 53-208.

3. The work of the field's founding father therefore evolved to a' history of management'. Thomas Hughes, Rescuing Prometheus (N.Y.: Pantheon, 1998).

4. This critical point was made in John Law, "Introduction: monsters, machines and sociotechnical relations" in John Law (ed.), A sociology of monsters: essays on power, technology and domination (London/N.Y.: Sage, 1991), 12; and Michael Hằrd, "Beyond harmony and concensus: A social conflict approach to technology" in Science, technology and human values Vol. 18 (1993), 408-431 on 413.

5. Cathrine Bertho-Lavenir, "The telephone in France 1879-1979: national characteristics and international influences" in Renate Mayntz \& Thomas Hughes, The development of large technical systems (Frankfurt am Main/Boulder, 1988), 155-178; Erik van derVleuten,"Constructing centralized electricity supply in Denmark and the Netherlands: An actor group perspective", Centaurus Vol. 41 (1998), 3-36; Arne Kaijser, "The helping hand. In search of a Swedish institutional regime for infrastructural systems" in Lena Andersson-Skog \& Olle Kranz (eds.), Institutions in the transport and communication industries (Canton, Ma: Science history publications, 1998), 223-244. Volker Schneider,"The governance of Large Technical Systems: The case of telecommunications" in Todd La Porte (ed.), Social responses to large technical systems. Control or anticipation (Dordrecht: Kluwer, 1991), 19-42.

6. Arne Kaijser, "Technological systems in the natural world: Water and windmills in the Netherlands" in Jan Odhnoff \& Uno Svedin, Technological systemic changes and economic theories (Stockholm, 1998). 
7. For the following see Van deVen, Man-made lowlands.., Ch. 2. and Kaijser, "technological systems in the natural world".

8. Kaijser, "technological systems in the natural world".

9. Van de Ven, Man-made lowlands, 41.

10. Kaijser,"technological systems in the natural world".

11. Jan deVries, Barges and capitalism. Passenger transportation in the Dutch economy, 16321839 (Utrecht: HES, 1981), 17 ff.

12. Ibid., 328.

13. T. Stol, "De waterbeheersing van circa 1600 tot circa 1800 " in van de Ven (ed.), Manmade lowlands, Dutch orig.,117-152 on 139-142.

14. Kaijser, "technological systems in the natural world".

15. A. Bosch \& G. P. van deVen, "Water en Staat. De waterstaat in Nederland vóór 1795”in Lintsen (ed.), Twee eeuwen Rijkswaterstaat.., 19-30 on 26.

16. Arne Kaijser, personal communication.

17. Bosch \& van de Ven, "Water en staat", 19.

18. Lintsen (ed.), Twee eeuwen Rijkswaterstaat, part I. For a brief English summary see H.W. Lintsen, Decline and rise of Rijkswaterstaat. Two centuries of history (Ministry of Transport, Public Works and Water Management, 1998)

19. For 19th century works see Van der Woud et. al., "Waterstaat en infrastructuur", in Lintsen et. al. (eds.), Geschiedenis van de techniek in Nederland. 1800-1890. Vol. 2, 95176 and Lintsen (ed.), Twee eeuwen Rijkswaterstaat, part I.

20. For 20th century projects see also Disco (ed.), "Waterstaat" in Schot (ed.), Techniek in Nederland.

21. Ibid.

22. H. W. Lintsen \& M. L. ten orn-van Nispen, "De Waterstaat rond 1900" in Schot et. al. (ed.), Techniek in Nederland in de 20e eeuw. Vol. I, 65-69 on 65-66.

23. H. W. Lintsen, "Organisatie op een keerpunt" in Lintsen (ed.), Twee eeuwen Rijkswaterstaat, $285 \mathrm{ff}$. and Lintsen, Decline and rise...

24. Van der Ham, Heersen en beheersen, 315-317.

25. Hughes, Rescuing Prometheus, Ch. 5 and Ch. 7.

26. C. Disco \& M. L. ten Horn-van Nispen, "Op weg naar een integraal waterbeheer" in Schot et. al. (ed.), Techniek in Nederland ... Vol. 1, 182-197 on 188-189.

27. C. Disco,"Remaking Nature.'The ecological turn in Dutch water management." Science, Technology and Human Values, forthcoming, april 2002.

28. Ibid., 322-324 and 335-341; Disco \& Horn- ten Nispen, "Op weg naar ..", 189-190.

29. Ministry of Transport, Public Works and Water Management, Omgaan met water (The Hague, 1985).

30. Parliament, Derde nota waterhuishouding (The Hague, 1989).

31. Thus conclude Disco \& ten Horn-van Nispen, "Op weg naar een integraal waterbeheer..", 197.

32. For the new weirs see: Th. Rehbock, K.E. Hildegard and P. Gerhardt, Wehre und Fischwege. 1st section, 2nd vol., part III of G. Franzius et al. (eds.) Handbuch der Ingenieurwissenschaften, Leipzig, Wilhelm Engelman, 1912; H. Kulka, Theorie und Konstruktion der beweglichen Wehre. Der Eisenwasserbau. Band I. Berlin, 1928.

33. Rapport van de Nederlandsch-Belgische Commissie ingesteld tot onderzoek van de kanalisatie van de gemeenschappelijke Maas. The Hague, 1912

34. Ibid. P. 21.

35. Letter minister waterstaat to inspectors-general Rijkswaterstaat, 27 may, 1925. ARA Archief Inspecteurs Rijkswaterstaat, 2.16.07, pakket 8524 .

36. Rijkswaterstaat, Directie. ZH, Milieu-effect Rapportage Beheer Haringolietsluizen. Over de grens van zout en zoet. 1998.

37. Kaijser, I fädrens spår, , Ch.3 and p. 49.

38. Ibid., 39, 83, 90-94. 